\title{
Identifiy student's attitude towards the subject of natural science
}

\author{
Astalini, Dwi Agus Kurniawan, Darmaji, Aqina Deswana Putri, Retno Nawangsih \\ Physics Education, Universitas Jambi, Indonesia
}

\begin{tabular}{l} 
Article Info \\
\hline Article history: \\
Received May 17, 2019 \\
Revised Jun 24, 2019 \\
Accepted Jul 17, 20 \\
\hline Keywords: \\
Attitude of science \\
Carrer interest \\
Fun \\
Middle school \\
Multiple time
\end{tabular}

Corresponding Author:

Aqina Deswana Putri, Physics Education, Universitas Jambi, Jl. Raya Jambi-Muara Bulian Mendalo Indah, 36361, Jambi, Indonesia. Email: aqinaputri@gmail.com

\begin{abstract}
The purpose of this research is to know how the attitude of junior high school students to science mathematics with three indicators adopted from TOSRA are: 1) pleasure in learning science, 2) interest to increase study time of science, and 3) interest in a career in the science field. This research uses survey type research with design research is quantitative design. This research was conducted in several junior high schools in Muaro Jambi district with total 2815 of total students. The instruments used are attitude questionnaires and interview sheets. The data analysis used for quantitative data is the descriptive statistical type and reinforced by interview analysis. The result of the research shows that students with the indicator of pleasure in learning science, and interest in increasing the study time dominant IPA has a good attitude category, while the indicator of career interest in the field of IPA dominant has a fairly good attitude category.
\end{abstract}

Copyright @ 2019 Institute of Advanced Engineering and Science. All rights reserved.

\section{INTRODUCTION}

The level of education in Indonesia starts in elementary school, junior high school, high school, and college. Based on the curriculum used in Indonesia the assessment of learning consists of affective, cognitive and psychomotor assessments. Meanwhile, "Learning Processes in educational units are held interactively, inspiratively, fun, challenging, motivate learners to participate actively, and provide sufficient space for the initiative, creativity, and independence in accordance with the talents, interests, and development of physical and psychological learners "[1]. Education at secondary school level especially junior high school has a more complex learning process than elementary school. This level of students is required to think in a focused, logical and scientific one of which is the science lesson. "Science learning has a" science for all "slogan that will reinforce that science is important for students in introducing problems, including into the introduction of complex personalities, environments, and sociocultural issues" [2].

Science learning aims to encourage students to understand the symptoms that are formed in nature, one of which is the relationship between man and nature. [3] that to know the symptoms that occur in the students are required to understand and explore the environment around the students. Based on the individual character of the learner, it is known that the existence of individual differences although having similar background and age will show the ability, appearance, temperament or emotion as well as the interests and attitudes that diverse. Attitude is defined as a core part of human identity [4]. "Attitude is also defined as a person's feelings and beliefs towards an object"[5]. In line with that [6] said that "attitude is described as the mental state of an individual against the object or problem faced, so as to change the mental state of the individual." That is, very important attitude is owned by students, especially students at the junior level. 
The importance of attitudes to Natural Science learning in junior high schools is seen from the actions of these students in learning that exhibit positive or negative attitudes toward Natural Science. Increased assessment of Natural Sciences at the time of learning will be seen in the high positive attitude of students to the learning of Natural Sciences such as students more actively working on the problem of Natural Science, active discussion and questions about the problems of Natural Sciences, focus on pay attention to teachers explain the material of Natural Science, etc. [7] when students have a positive attitude toward science then performance in all things will be optimal. As for the negative attitude is seen based on the low assessment of science at the time of learning based on the seriousness of students when learning Natural Science, students tend not to focus when teachers explain the science material, students are lazy to learn is marked by sleepy and grabbed while studying science.

[8] the low academic value of students is based on poor student and teacher interaction leading to negative attitudes toward learning materials. Lack of knowledge from teachers about weak student attitudes toward natural science subjects exacerbates situations where students' negative attitudes toward Natural Science will increase. [9] negative attitudes toward students 'own science will affect students' unhappiness in science subjects and teachers who teach science. While a positive attitude toward the subjects of Natural Sciences should be owned by every student because a positive attitude toward Natural Science affects students' feelings, students' understanding, and students' behavior on the subjects of Natural Sciences. This opinion is explained by [10] who said that "attitude is a picture of every kind of human reaction that is in the main component of emotion, cognitive and behavior of a person against something". [7] individual attitudes that lead into the affective domain can be changed to determine whether the cognitive component can produce optimal results. This shows the importance of a teacher to be able to observe and analyze how students' attitudes about the subjects of Natural Sciences, so that students can be passionate and participate in every learning.

[11] research in Science education shows that there are several factors that influence students' attitudes toward science based on "Test of Science-Related Attitudes (TOSRA). Based on this, the dimensions of attitudes toward science subjects that will be measured in this study adopted from Fraser's TOSRA (1981) are: 1) the pleasure in learning Natural Science, 2) interest in increasing the study time of Natural Science, and 3) interest career in the field of Natural Sciences.

Pleasure in learning Natural Science will give a positive influence on the development of student learning on science subjects. [12] say the positive effects on science subjects are derived from the taught material, methods and media used in learning, the ability of teachers while teaching, as well as the physical and social environment of students who support these students to enjoy learning. [13] that this interaction creates a pleasant emotion when acquiring new knowledge related to the understanding of an object of that knowledge. The pleasure in learning Natural Science is also able to provide a good focus on students, so that will achieve the expected learning objectives. [14] Teachers should try to make science lesson a fun lesson, which the students will remember for their lives even though the student has graduated from school. In addition, with the enjoyment of learning I Natural Science students have the interest to increase the time of learning Natural Science.

Interest in expanding the study time of Natural Sciences because the material in learning Natural Science is not only needed an explanation of the theory but also its application in everyday life. Such learning is undertaken when activities focusing on acquisitions that are difficult or not can be done in a classroom but can be done in nature or the environment [15]. Since life in the world today is inseparable from events in Nature as well as scientific laws, Natural Science has become part of general education [16]. The general education that teaches Natural Science, in fact, affects students' attitudes toward Natural Sciences and becomes one of the most important variables in determining student achievement [17]. Based on the sentence shows that the subjects of Natural Sciences are very important to learn.

By increasing the study time of science students are also able to think logically and scientifically and show students have fun in learning Natural Science. Based on this, if the students already have a high pleasure on the learning of Natural Sciences as well as the desire to increase the study time of Natural Sciences then the next will settle and continue his career in the field of Natural Sciences as well. The interest to continue his career in the field of Natural Sciences cannot be separated from how large the individual has a belief that a career in the field of science is one of the desires for his future. In connection with that, [18] say. "That success can be interpreted as how good the students do in all their duties without wasting time". In other words, interest in a career in the field of Natural Sciences can improve students' attitudes toward Natural Sciences, but not all students choose a career in the field of Natural Sciences. [19] argue that "male students are more likely to choose careers in the field of Natural Sciences, unlike some still have some negative attitudes toward the subject of Natural Sciences". [20] said that the application of curriculum and technology used by teachers in teaching as well as the changing student environment becomes a factor of negative feelings towards the Natural Science. 
The purpose of the study is expected to facilitate the teacher in knowing the obstacles and problems faced by students' attitudes when studying Natural Science. In this study, the questions addressed are:

a. Describe the attitude indicators on the subjects of Natural Sciences?

b. What do students think about attitudes toward the subjects of Natural Sciences?

c. What problems do students face about attitudes toward the subjects of Natural Sciences?

d. What solutions can be made in improving students' attitudes toward the subjects of Natural Sciences?

The findings of this study may contribute to improving students' positive attitudes toward the subjects of Natural Sciences in Junior High School educational institutions, especially in Indonesia and other countries. This can be seen in the Junior High School in Muaro Jambi District which has a problem for the students that is a negative attitude toward the subject of Natural Science. This research will be aimed at assisting teachers in improving students 'understanding and students' behavior on science subjects in school.

\section{RESEARCH METHOD}

The type of research used is the type of survey research with research design is a quantitative design. [21] "The direction of survey research is to analyze the characteristics of the population" The main purpose of this research design is to improve the quality of teaching in achieving the objectives of learning. The design of this study was also conducted in accordance with the purpose of research that is as a measure of student attitudes toward the subjects of Natural Sciences School Intermediate in Muaro Jambi.

Is done because the researchers want to see the attitude of all students in grade VII and VIII in Muaro Jambi regency of Natural Sciences with total samples for charging questioner as a total sampling technique of 2815 students consisting of women 1560 students with weight $55 \%$ of the total and male 1255 students $45 \%$ of the total. While the technique of taking purposive sampling data with the conduct of interviews as many as 36 students as a questionnaire data amplifier.

Instruments used are questionnaires and interviews. Type of questionnaire instrument used the closed type with the number of 54 statements that explain the positive and negative attitude of students to the learning of Natural Sciences. The scale used in this attitude questionnaire instrument is a five-point Likert scale consisting of (STS = strongly disagree, TS = disagree, $\mathrm{N}=$ neutral, $\mathrm{S}=$ agree, $\mathrm{SS}=$ strongly agree). Instrument attitude toward science learning using attitude indicator with three indicator that is Pleasure in studying science amounted 10 statement, Characteristic multiply study time IPA amounted to 8 statement, interest of thinking in field of natural science amounted 10. the results of 28 statements from 3 indicators of students' attitudes toward the subjects of Natural Sciences seen in Table 1.

Table 1. Statement and indicator of attitude to science subjects

\begin{tabular}{|c|c|c|c|c|c|}
\hline \multirow{2}{*}{ No } & \multirow{2}{*}{ Variables } & \multirow{2}{*}{ Indicator } & \multicolumn{2}{|c|}{ Statement } & \multirow{2}{*}{ Total Item } \\
\hline & & & Positive $(+)$ & Negative (-) & \\
\hline 1 & & En & $5,19,33,43,51$ & $12,26,38,47,53$ & 10 \\
\hline 2 & Students Attitude & Leisure Interest $\mathrm{i}$ & $6,20,34,44$ & $13,27,39,48$ & 8 \\
\hline 3 & & Career Interest in Science & $14,28,40,49,54$ & $7,21,35,45,52$ & 10 \\
\hline
\end{tabular}

In addition to the instruments in this study also used semi-structured interviews. This type of interview is freer than structured interviews. This interview aims to obtain information about students' attitudes toward the subjects of Natural Sciences. This research procedure is done starting from spreading the questionnaire, then analysis of attitude questionnaire data then continue with the interview and finally proceed with transcribing all data of result which have been obtained during the research.

The data analysis used in this research are 2 types of descriptive statistic data for the quantitative data in the form of mean, mode, median, standard deviation, further strengthened using data analysis interview in the form of data reduction, data presentation, and conclusion.

\section{RESULTS AND ANALYSIS}

Attitudes toward the Natural Sciences of education fall into the cognitive parts seen in students. Attitude is a positive or negative tendency of an individual to a certain place, atmosphere, or object. Usually, this attitude arises from the visible changes in the behavior of a person when faced with a certain subject or object, [22] attitude that someone does usually affect the behavior and how to act personally in a big situation. To achieve the goal of education requires a high positive attitude in students, in line as expressed 
[23] the increase of positive attitude will affect the future of the younger generation and the next generation. This shows that positive attitude is very influential and play an important role in improving the quality of student learning is the same that revealed by [24] attitude is very influential in shaping the individual experience through a particular object. Based on the above, the attitude towards the subjects of Natural Sciences is divided into 1) pleasure in learning Natural Science, 2) interest to increase the study time of Natural Science and 3) interest in a career in the field of Natural Sciences.

\subsection{Enjoyment of science lesson}

Analysis of statistical data on student attitude attitudes toward the Natural Sciences in the indicators of pleasure in the field of Natural Sciences can be measured through the views of students who think that learning Natural Science is not difficult. This can be seen based on the translation of data in Table 2.

Table 2. Level enjoyment of science lesson

\begin{tabular}{|c|c|c|c|c|c|c|c|c|c|}
\hline No & Range & Attitude & Total & Mean & Median & Modus & Std.deviation & Min & Max \\
\hline 1 & $10 \mathrm{~s} / \mathrm{d} 18$ & Very Not Good & 8 & & & & & & \\
\hline 2 & 19 s/d 26 & Not Good & 109 & & & & & & \\
\hline 3 & 27 s/d 34 & passable & 835 & 36,9327 & 37 & 38 & 5,88779 & 12 & 50 \\
\hline 4 & $35 \mathrm{~s} / \mathrm{d} 42$ & Good & 1350 & & & & & & \\
\hline 5 & $43 \mathrm{~s} / \mathrm{d} 50$ & Very Good & 513 & & & & & & \\
\hline
\end{tabular}

Based on the table The statistics above show that $0.28 \%$ ( 8 of 2815 students) are classified as very unfavorable, $4 \%$ (109 of 2815 students) belonging to the bad category, 30\% (835 of 2815) fall into the category good enough, $48 \%$ (1350 of 2815 students) belong to the good category, and students who fall into very good category $30 \%$ ( 835 of 2815 students). this shows some students already have a positive attitude towards the learning of Nature Science by showing the pleasure in learning Natural Science.

The pleasure in learning Natural Science for students is seen from its positive attitude towards the science course of Nature itself. How are they dealing with time on Natural Science learning, and how students' satisfaction on the subject of Natural Science. Data analysis in this study was done measuring student attitudes toward pleasure in the lesson of Natural Science which can be measured through questionnaires to all students of class VII and VIII Junior High School in Muaro Jambi District. With a total of 2815 students. Based on data analysis shows the attitude of junior high school students in Mauro Jambi district has the dominant percentage in a good category as much as 48\% (1350 of 2815 students).

Good category contained in this indicator because the teacher who teaches the theory with a series so that students are able to understand the lesson well. In addition, many teachers provide motivation that encourages the activity and creativity of students. [25] every teacher should make every effort to improve students' learning pleasure to produce the best value by building a pleasant learning environment.
Question
: Do you like the science course?
Answer $\quad$ :Yes, I am pretty fond of Science Sciences
Question : What is the reason you love science lessons?
Answer $\quad:$ But what I do not like about the science course is too many concepts and formulas to understand. It all depends on the teacher who teaches in the class.
Question : When learning how the teacher teaches Natural Science in the classroom?
Answer : My first monotonous teacher just explained what's in the book, but the teacher is now better, fun, not monotonous and I like it.

The results of interviews that have been done show the students' attitudes toward the natural science mathematics in the good category. [26] students will be good at learning if the students are in love with natural science subject. This is because the lessons of Natural Science are interesting, telling a lot about nature and everyday life. Based on the students' answers, the teacher of Natural Science subject now teaches Natural Science well and not monotone. In addition, according to students the things that are not preferred from the lessons of Natural Sciences because too many concepts and formulas that must be understood that resulted in fewer students like science lessons. [27] if students do not like the lesson then the students do not try to understand the meaning of the concept that is taught. 
Question : Do you like the natural science lesson taught in school?

Answer $\quad$ : No, I do not like Natural Science lessons taught by teachers at the school

Question : What makes you not like the science lessons at school?

Answer : Because Natural Science is a difficult subject, must be smart analysis problems, formulas, and material that must be studied too much so dizzy. Learning Natural Science in school makes sleepy difficult to focus because the Nature Sciences is not interesting and very boring

Results of interviews conducted with students on the indicator of learning pleasure which shows a negative attitude to the Natural Sciences by assuming that learning Natural Science is difficult, students do not like to learn Natural Science, the boredom in students when learning Natural Science so at learning Natural Science students cannot focus on following the learning of Natural Sciences, among others, assume that learning science in school make sleepy. [8] negative attitudes toward objects lead to a lack of students' desire to attend and participate in any activity related to the subject.

\subsection{Leisure interest in science}

Analysis of statistical data of student attitude attitudes toward Natural Sciences on the indicator of interest to increase the study time Natural Science can be measured through the indicator of interest to increase the study time of Natural Sciences by looking at the interest of students in the world of science with his attitude that likes to read about science, experimenting to spend time in the lab. Based on the elaboration of the following statistical data in Table 3.

Table 3. Level of leisure interest in science

\begin{tabular}{|c|c|c|c|c|c|c|c|c|c|}
\hline No & Range & Attitude & Total & Mean & Median & Modus & Std.deviation & Min & Max \\
\hline 1 & $8 \mathrm{~s} / \mathrm{d} 14,4$ & Very Not Good & 7 & & & & & & \\
\hline 2 & $14,5 \mathrm{~s} / \mathrm{d} 20,8$ & Not Good & 135 & & & & & & \\
\hline 3 & $20,19 \mathrm{~s} / \mathrm{d} 27,2$ & Passable & 1150 & 27,9805 & 28 & 26 & 4,52687 & 11 & 40 \\
\hline 4 & $27,3 \mathrm{~s} / \mathrm{d} 33,6$ & Good & 1213 & & & & & & \\
\hline 5 & $33,7 \mathrm{~s} / \mathrm{d} 40$ & Very Good & 310 & & & & & & \\
\hline
\end{tabular}

Based on the statistical data table this study illustrates that there is $0.25 \%$ ( 7 of 2815 students) who have very bad category, 5\% (135 of 1815 students) categorize not good, $41 \%$ (1150 out of 2815 students) had good enough category, $43 \%$ (1213 of 2815 students) had good category, and 11\% (310 out of 310 students) had very good category. This shows almost some students have a positive attitude towards the learning of Natural Sciences by showing the interest of students to increase the study time of Natural Sciences.

Students' pleasure in the course of Natural Sciences also has a linkage to the increased interest in studying Natural Science which explains how students are addressing the subjects of Natural Sciences, filling their spare time by reading literature related to Natural Sciences and visiting the laboratory. The result of data analysis shows that the attitude of Junior High School students in Muaro Jambi District is dominant in a good category with percentage 43\% (1213 from 2815 students) of total. The good category that existed in the junior high school students of Muaro Jambi can be achieved because students consider that with the addition of time, and free time given by the teacher, can provide insights related to information available in the environment about Natural Science with a lot of reading the literature on science and spend time in the laboratory of Natural Sciences. [28] additional time for individuals can provide new experiences, improve skills, and provide opportunities for individuals to gain new insights.

\footnotetext{
Question : What is your response if the school hours of Science in the school are multiplied?

Answer : I am glad because if the lesson is reproduced I will better understand the concepts and formulas given by teachers in the class

Question : Do you often read the literature on Natural Science at home?

Answer : :Yes, I often read the literature on the natural science at home, in addition, I also like watching videos and searching for interesting things on the internet Natural Science.
}

Based on the results of interviews done look positive attitude of students to science mathematics by wanting to increase the time to learn Science Natural. If lesson time is added then the students will better understand the concepts and formulas given by teachers in the classroom. In addition, interest in increasing the study time of Natural Sciences is not only obtained from reading literature at home but also obtained by watching a student video on youtube and searching for interesting things on the internet about Natural 
Science. [29] Positive attitudes that students have on subject reflected by the desire of students to add and take the time to learn to find things related to the lesson.

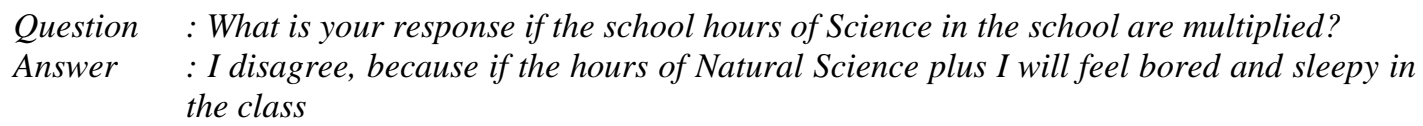

Question : Do you often read the literature on Natural Science at home?

Answer : : No, I do not like to read literature at home because it is wasted time

Based on the results of the interviews, the students' negative attitude towards the natural sciences lessons by wanting to increase the study time of Natural Sciences. If the natural science lessons are added then the students will feel bored and sleepy. Besides, the lack of interest to increase the study time of Natural Sciences is not seen from the negative attitude shown by the students only in school but the attitude of the students if they are at home by assuming that reading books and literature on Natural Science at home just wasted time. Seen from the interview that students have less desire and motivation to increase the study time of Natural Sciences in school and spend time at home with the change of behavior of students [30] "The purpose of many researchers to observe and research is to motivate students to be able to participate in their learning process, so that there are differences in behavior".

\subsection{Carrer interest in science}

Analysis of statistical data questionnaires student attitudes toward the Natural Sciences on the indicator of career interest in the field of Natural Sciences can be measured by looking at how much the students desire a career in the field of science, be it a scientist or in the laboratory. This can be seen based on the elaboration of statistical data in Table 4.

Table 4. Level career interest in science

\begin{tabular}{|c|c|c|c|c|c|c|c|c|c|}
\hline No & Range & Attitude & Total & Mean & Median & Modus & Std.deviation & Min & Max \\
\hline 1 & $10 \mathrm{~s} / \mathrm{d} 18$ & Very Not Good & 10 & & & & & & \\
\hline 2 & 19 s/d 26 & Not Good & 149 & & & & & & \\
\hline 3 & 27 s/d 34 & passable & 1177 & 35,075 & 35 & 36 & 5,82294 & 12 & 70 \\
\hline 5 & $43 \mathrm{~s} / \mathrm{d} 50$ & Very Good & 319 & & & & & & \\
\hline
\end{tabular}

Based on the statistical data table the results of this study illustrate that there are $0.36 \%$ (10 of 2815 students) are not very good, 5\% (149 of 2815 students) category is not good, $42 \%$ (1177 of 2815 students) category is good enough, $41 \%$ (1160 of 2815 students) good category, and $11 \%$ (319 out of 2815 students) who have very good category. This shows the more dominant students answer neutral on the filling of the questionnaire so that not many students who have a good attitude towards the learning of Nature Science by showing interest in a career in the field of Natural Sciences.

Students who have fun in Natural Science learning and students who wish to increase the study time of Natural Sciences will also continue their career in Natural Sciences. interest in a career in the field of Natural Sciences, which explains the desire of students to continue their education to a higher level and apply the knowledge obtained in the field of Natural Sciences. [31] students' attitudes toward Natural Science affect the future of students and their careers. such as teaching in the field of Natural Sciences, working at the laboratory, becoming a scientist of Natural Sciences, and so forth. Based on data analysis conducted on all students of class VII and VIII in Junior High School in Muaro Jambi District, the students are more dominantly categorized as good enough with the percentage of $42 \%$ (1177 out of 2815 students) of total students.

Question: Are you interested to pursue a career in Natural Sciences?

Answer 1 : I am not interested in a career in the field of Natural Sciences because, what I see in the books of scientists it has a messy lifestyle, and also work in the field of Natural Sciences also requires high energy and science

Answer 2 : I like to study Science Natural Science, but I do not want to work in the field of Natural Science because working in the field of Natural Science is very waste of time

Answer 4 : I love science lessons and would love to work in the field of Natural Sciences because it can be cool to use lab coats every day and have a fairly large income. 
Based on the results of interviews conducted with students who have good enough category has a variety of answers. There are students who like learning Natural Science but do not want to continue his career in the field of science because students assume a worker in the field of IPA will have a bad life, requires a great manpower and high science. [32] Positive and negative attitude on the learning process will affect the future and individual person. In addition, there is also the assumption of some students who say like science lessons but do not want to work in the field of Natural Sciences because working in the field of science wasting time alone. The results of other interviews there are students who say like to the lessons of Natural Sciences and want to continue his career in the field of science because it can use a lab coat at all times and earn a fairly large income. In line with what [33] says students who hold the notion that a career will generate a lot of money will tend to be interested and will settle and survive in a career that will help in meeting the needs of his life

\section{CONCLUSION}

Based on the results obtained from the grade level of students' attitudes toward the IPA shows that the high level of pleasure in learning Natural Sciences and interest increase the study time Natural Science does not allow students to choose a career in the field of Natural Sciences. While [34] argues that Growing positive attitude of students to the subjects of Natural Sciences can increase student interest and career in the field of Natural Sciences. In other words, this opinion contradicts the results obtained in Junior High School students in Muaro Jambi district. This situation is caused by the low desire of students to work and career in the field of Natural Sciences. [35] increasing growth and technology quickly turns students' interest in science down as well as a career in science. Like being a scientist, working in a laboratory, being a teacher or a lecturer in Natural Sciences, In addition, their assumption that at a higher level of education, the lessons of Natural Science more difficult and to achieve career aspirations in the field of Natural Sciences takes a long time.

\section{ACKNOWLEDGEMENTS}

The author would like to thank for my parent who has provided support. The author also expressed his gratitude the respondents who were willing to take the time and contribute in providing data for this study.

\section{REFERENCES}

[1] Minister of Education and Culture's Regulations Republic of Indonesia Number 65. About Process Standards (in Bahasa). 2013.

[2] Lederman, N. G., and Abell, S. K., Scientific Literacy, Science Literacy, and Science Education. Handbook of Research on Science Education Routledge, pp. 546, 2017.

[3] Anggoro, S., Sopandi, W., and Salahuddin, M., "Influence of Joyful Learning on Elementary School Students'Attitudes Toward Science," Journal of Physics: Conf. Series 812, 2017.

[4] Mohamed, L., and Waheed, H., "Secondary Students' Attitude towards Mathematics in a Selected School of Maldives," International Journal of Humanities and Social Science, vol. 1 no. 15, pp. 277-281, 2011.

[5] Kind, M. P., Jones, K., and Bamby, P., "Developing attitudes towards science measures," International Journal Of Science Education, pp. 1-4, 2007.

[6] Cooper, J., Blackman, S. F., and Keller, K. T., The Science of Attitudes. New York: Routledge, 2016.

[7] Godwin, B. A., and Okoronka, U. A., "Attitude And Academic Performance Of Senior Secondary School Students In Physics In Nigeria," International Conference on Education, pp. 499-506, 2015.

[8] Sitotaw, B. and Tadele, K., "Students attitudes towards physics in primary and secondary schools of Dire Dawa City administration, Ethiopia," World Journal of Educational Research and Reviews, pp. 1-8, 2016.

[9] Guido, R. M., "Attitude and Motivation towards Learning Physics," International Journal of Engineering Research \& Technology (IJERT), 2013, vol. 2, no. 11, pp. 2087, 2013

[10] Veloo, A., Nor, R., and Khalid, R., "Attitude towards Physics and Additional Mathematics Achievement," International Education Studies, vol. 8. no. 3, pp. 35-43, 2015.

[11] Anwer, M., Iqbal, H. M., and Harrison, C., "Students' Attitude towards Science: A Case of Pakistan," Pakistan Journal of Social and Clinical Psychology, pp. 3-7, 2012.

[12] Chopra, V., and Chabra, S., "Digantar In India: A Case Study For Joyful Learning," Journal of Unschooling and Alternative Learning, pp. 29-43, 2013.

[13] Levine, D. S., "I think therefore i feel: Possible neural mechanisms for Knowledge-based Pleasure," IEEE World Congress on Computational Intelligence, 2012.

[14] Narmadha, U., and Chamundeswari, S., "Attitude towards Learning of Science and Academic Achievement in Science among Students at the Secondary Level," Journal of Sociological Research, pp. 114-118, 2013. 
[15] Ozer, D. Z., and Gungor, S. N., "Analysis of Middle School Students' Views and Impressions about a Science Center," Journal of Turkish Science Education, pp. 109, 2017.

[16] Prakash, S. and Xavier, S. A., "A Study On Attitude Of Urban And Rural College Student," i-manager's Journal on Educational Psychology, vol. 7, no. 3, pp. 13, 2014.

[17] Kirikkaya, E. B., "Grade 4 to 8 primary school students' attitudes towards," Educational Research and Reviews, vol. 6 , no. 4 , pp. $375,2011$.

[18] Crumb, C. R., Moore, C., and Wada, A. R., "Who Wants to Have a Career in Science or Math? Exploring Adolescents' Future Aspirations by Gender and Race/Ethnicity," Science Education, pp. 459-460, 2010.

[19] Bang, E., and Baker, D. R., "Gender differences in Korean high school students' science achievements and attitudes towards science in three different school settings," Mevlana International Journal of Education, vol. 3, no. 2, pp. 27-42, 2013.

[20] Hacieminoglu, E., "Elementary School Students' Attitude toward Science and Related Variables," International Journal of Environmental \& Science Education, vol. 11, no. 2 pp. 35-52, 2016.

[21] Kerlinger, F. N., Foundations of Behavioural Research. Yogyakarta: Gajah Mada University Press, 2014.

[22] Sakariyau, A. O., Taiwo, M. O., and Ajagbe, O. W., "An Investigation of Secondary School Students' Attitude," Journal of Education and Practice, vol. 7, no. 28, 2016.

[23] Turkmen, L., " In-service Turkish elementary and science teachers' attitudes toward science and science teaching: A sample from Usak province," Science Education International, vol. 24, no. 4, pp. 437-459, 2013.

[24] Akinbobola, A. O., " Enhancing Students' Attitude Towards Nigerian Senior Secondary School Physics Through The Use Of Cooperative, Competitive And Individualistic Learning Strategies," Australian Journal of Teacher Education, vol. 34, no. 1, pp. 1-9, 2009.

[25] Pell, A. W., "Enjoyment and Attainment in Secondary School Physics," British Educational Research Journal, vol. 11, no. 2, pp. 123-132., 1985.

[26] Daud, A. M., Omar, J., Turiman, P., and Osman, K., "Creativity in science education," Procedia-Social and Behavioral Sciences, vol. 59, pp. 467-474, 2012.

[27] Hofstein, A. and Naaman, R. M., "High-School Students' Attitudes toward and Interest in Learning Chemistry," International year of chemistry [attitude toward chemistry], pp. 90-91, 2011.

[28] Edginton, C. R. and Chen, P., Leisure as Transformation. Champaign, IL: Sagamore Publishing, 2008.

[29] Hartinah, S. and Setiawan, T., "Kindergarten Teachers' Attitudes Towards Mathematics Learning (in Bahasa)," Jurnal Ilmu Pendidikan, vol 19, no. 1, pp. 50-55, 2013.

[30] Sinatra, G. M., Heddy, B. C., and Lombardi, D., "The Challenges of Defining and Measuring Student Engagement in Science," Educational Psychologist, vol. 50, no. 1, pp. 1-13, 2015.

[31] Owen, S. V., Toepperwein, M. A., Marshall, C. E., Lichtenstein, M. J., Blalock, C. L., Liu, Y., et al., "Finding Pearls: Psychometric Reevaluation of the Simpson-Troost Attitude Questionnaire (STAQ)," Science Education, vol. 92, no. 6:1076-1095, 2008.

[32] Kaya, H., and Boyuk, U., "Attitude towards Physics Lessons and Physical Experiments of the High School Students," European journal of physics education, vol. 2, no. 1, pp. 23-31, 2011.

[33] Hazari, Z., Sonnert, G., Sadler, P. M., and Shanahan, M. C., "Connecting high school physics experiences, outcome expectations, physics identity, and physics career choice: A gender study," Journal of research in science teaching, vol. 47, no. 8, pp. 978-1003, 2010.

[34] Liaghatdar, M. J., Soltani, A., and Abedi, A., " A Validity Study of Attitudes toward Science Scale among Iranian Secondary School Students," International Education Studies, vol. 4, no. 4, pp. 36-46, 2011.

[35] Nasr, A. R., and K, A. S., "Attitude towards Biology and Its Effects on Student's Achievement," International Journal of Biology, vol. 3, no. 4, pp. 100-104, 2011.

\section{BIOGRAPHIES OF AUTHORS}

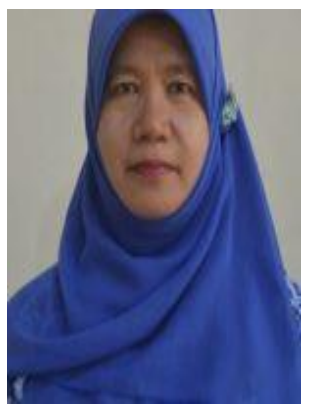

Astalini, is a lecturer at the Universitas Jambi. Born in 1963. Completed undergraduate education at IKIP Padang and postgraduate education at the Institut Teknologi Bandung 


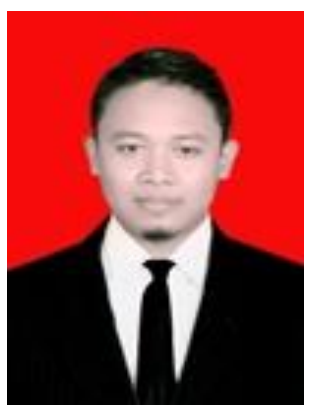

Dwi Agus Kurniawan, is a lecturer at Universitas Jambi. Born in 1983. completed his undergraduate education at Universitas Jambi and continued his S2 education at Universitas Negeri Yogyakarta.

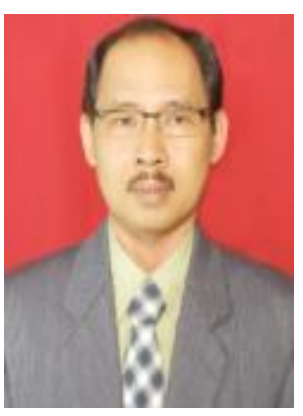

Darmaji is a lecturer at Universitas Jambi. Born in 1963. completed his undergraduate education at Universitas Negeri Lampung (UNILA) and continued his S2 education at Universitas Gajah Mada (UGM)

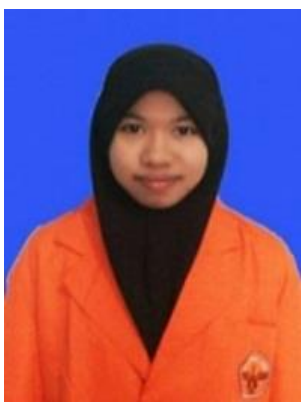

Aqina Deswana Putri was born in 1997 completing her first school education at Jambi City 19 Junior High School continuing her senior secondary education in Jambi City 4 State Senior High School and is now still a student at the universitas jambi of physics education program to run an undergraduate program

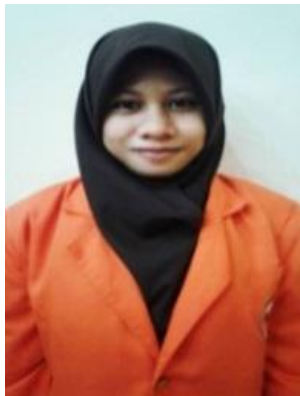

Retno Nawangsih was born in 1997 completing junior high school education in Sarolangun District 2 State Middle School, continuing high school education at Sarolangun District 1 State High School and until now still a student at Universitas Jambi taking a physics education study program. To run an S1 program 